\title{
Pengaruh Budaya Kerja Dan Motivasi Berprestasi Terhadap Kinerja Aparatur Sipil Negara
}

\author{
Roni Bintara ${ }^{1}$, Aldri Frinaldi ${ }^{2}$ \\ ${ }^{1}$ Magister Administrasi Publik, Universitas Negeri Padang, Padang, Sumatera Barat, Indonesia \\ ${ }^{2}$ Universitas Negeri Padang, Padang, Sumatera Barat, Indonesia
}

\begin{tabular}{|c|c|}
\hline ARTICLE INFORMATION & A B S T R A C T \\
\hline Received: February 02, 2021 & \multirow{7}{*}{$\begin{array}{l}\text { In fact, there are still many negative assessments of the performance of the State Civil Servants. One of the } \\
\text { factors that influence the performance of this State Civil Servant is the lack of a work culture that embodies } \\
\text { achievement. Besides, the motivation of employee achievement also affects performance, because if the } \\
\text { employee's motivation for achievement is high, the performance also will be high and it occurs on the contrary. } \\
\text { Therefore, this research aims to know the effect of the work culture and motivation for achievement on the } \\
\text { performance of the State Civil Servants at Bukittinggi Regional Ministry of Home Affairs Human Resource } \\
\text { Development Center. This research was conducted on } 65 \text { employees using random sampling techniques. The } \\
\text { results of the research indicated that the work culture and achievement motivation have a significant effect on } \\
\text { performance at Bukittinggi Regional Ministry of Home Affairs Human Resource Development Center. }\end{array}$} \\
\hline Revised: March 03, 2021 & \\
\hline Accepted: April 20, 2021 & \\
\hline Available online: April 25, 2021 & \\
\hline KEYWORDS & \\
\hline Achievement Motivation, Performance, Work Culture & \\
\hline CORRESPONDENCE & \\
\hline
\end{tabular}

Phone: +6285363600322

E-mail: ronibintara62@gmail.com

\section{PENDAHULUAN}

Dalam upaya untuk mewujudkan Aparatur Sipil Negara yang bernilai positif, maka diperlukan peningkatan sumber daya manusia aparatur yang berkualitas dan professional. Peningkatan dan pengembangan sumber daya aparatur ini harus diperhatikan oleh pimpinan organisasi pemerintah. Hal ini bertujuan untuk memberi pemahaman kepada aparatur dalam menjalankan tugas pokok dan fungsi secara baik dan benar (Widyastuti dan Waridin, $2006: 121$ ).

Akan tetapi, pada kenyataannya masih banyak ditemui permasalahan yang berkaitan dengan rendahnya kinerja Aparatur Sipil Negara. Salah satu faktor penyebab rendahnya kinerja Aparatur yaitu budaya kerja yang dapat mewujudkan prestasi belum terbangun, hal ini terkait karakter dan kultur positif budaya kerja yang berkembang masih memperlihatkan budaya kerja negatif.

Selain budaya kerja, motivasi berprestasi aparatur juga sangat mempengaruhi kinerja dari aparatur itu sendiri, karena jika motivasi berprestasi aparatur tinggi maka akan berdampak kepada kinerjanya yang juga akan tinggi dan sebaliknya. McClelland mengatakan motivasi berprestasi adalah ada sementara orang yang memiliki dorongan yang sangat kuat untuk mencapai suatu keberhasilan, dimana mereka lebih mengejar keberhasilan perorangan dari pada imbalan dari keberhasilan tersebut.

Berdasarkan pengalaman sebagian pihak dan diperkuat oleh temuan awal peneliti dilapangan dapat disimpulkan bahwa rendahnya motivasi berprestasi aparatur antara lain disebabkan oleh : Masih adanya ASN yang tidak memiliki rasa tanggungjawab terhadap tugas yang diberikan, masih kurangnya kreatifitas dan inovasi ASN dalam meyelesaikan tugas (terpaku dengan kebiasaan atau rutinitas yang telah ada), https://doi.org/10.35308/jpp.v7i1.3215 seringnya menunda-nunda pekerjaan yang diberikan. Rendahnya motivasi berprestasi ini juga disebabkan oleh kurangnya kepercayaan yang diberikan kepada ASN untuk melaksanakan suatu pekerjaan, sehingga karyawan merasa tidak percaya diri dalam menyelesaikan suatu pekerjaan. Selain itu, bagi ASN yang telah bekerja secara baik juga tidak begitu diperhatikan (tidak adanya umpan balik dari organisasi).

Berdasarkan pengamatan penulis yang dalam penjelasan diatas, maka penulis berminat untuk melakukan penelitian yang berjudul "Pengaruh Budaya Kerja dan Motivasi Berprestasi Terhadap Kinerja Aparatur Sipil Negara di Pusat Pengembangan Sumber Daya Manusia Kementerian Dalam Negeri Regional Bukittinggi". Asumsi dasar penelitian ini terdapat pengaruh budaya kerja dan motivasi berprestasi terhadap kinerja aparatur sipil negara di PPSDM Kementerian Dalam Negeri Regional Bukittinggi.

\section{METODE}

Penelitian ini dilakukan di PPSDM Kemendagri Regional Bukittinggi. Populasi dalam penelitian ini adalah seluruh Aparatur Sipil Negara PPSDM Kemendagri Regional Bukittinggi sebanyak 78 orang. Sedangkan teknik pengambilan sampel dalam penelitian ini menggunakan teknik Simple Random Sampling, dengan jumlah responden sebanyak 65 orang. Konsepsi penelitian menggunakan model path analysis (analisis jalur) dengan menggunakan bantuan SPSS (Statistical Package For The Sosial Science). Adapun penghitungan jalur menjelaskan bahwa pengaruh nilai budaya kerja (XI) dan motivasi berprestasi (X2) terhadap kinerja (Y) dan kausalitas budaya kerja (X1) terhadap motivasi berprestasi (X2). 


\section{HASIL DAN PEMBAHASAN}

Gambaran Umum Pusat Pengembangan Sumber Daya Manusia (PPSDM) Kementerian Dalam Negeri Regional Bukittinggi.

PPSDM Kementerian Dalam Negeri Regional Bukittinggi adalah Unit Pelaksana Teknis Lingkungan Kementerian Dalam Negeri yang berada di bawah dan bertanggung jawab kepada Menteri Dalam Negeri dan secara Teknis Fungsional dibina oleh BPSDM Kementerian Dalam Negeri dan dipimpin oleh seorang Kepala Pusat. PPSDM Kementerian Dalam Negeri Regional Bukitinggi ini mempunyai tugas melaksanakan pengembangan kompetensi dan uji kompetensi pemerintah dalam negeri yang berlokasi di Jalan Raya Bukittinggi Payakumbuh KM.14 Baso, Kabupaten Agam. Berikut disajikan Grafik 1. Profil Responden Penelitian.

Grafik 1. Profil Responden Penelitian

Jenis Kelamin

Berdasarkan hasil pengolahan data pada Grafik 1, ditemukan sebaran responden dengan jenis kelamin laki-laki adalah sebesar 38 orang (58.5\%), sedangkan responden yang berjenis kelamin perempuan sebanyak 27 orang (41.5\%) dari total sampel penelitian. Hal ini menunjukkan bahwa responden penelitian ini lebih dari separuhnya berjenis kelamin laki-laki dengan total 38 orang dibandingkan dengan yang berjenis kelamin perempuan 27 orang. Berikut disajikan Grafik 2. Usia Responden Penelitian.

Grafik 2. Usia Responden Penelitian

Usia
$30,8 \%$
$-20-30,4 \%$
$-26,2 \%$

Selanjutnya, dari segi usia bahwa sebaran rentang umur responden 20-30 tahun sebanyak 23 orang (35.4\%); 31-40 tahun sebanyak 17 orang (26.2\%); rentang umur 41-50 sebanyak 5 orang $(7.7 \%)$; dan umur 51-60 tahun sebanyak 20 orang $(30,8 \%)$. Responden paling banyak berada pada rentang umur 21-30 tahun yaitu sebanyak 23 orang dan yang paling sedikit berada pada umur 41-50 tahun yaitu sebanyak 5 orang. Dapat dikatakan bahwa pegawai Aparatur Sipil Negara di Pusat Pengembangan Sumber Daya Manusia Kementerian Dalam
Negeri Regional Bukittinggi didominasi oleh pegawai dengan rentang umur 21-30 tahun, yaitu sebanyak 23 orang (35.4\%). Berikut disajikan Grafik 3. Tingkat Pendidikan Responden.

Grafik 3. Tingkat Pendidikan Responden

\section{Tingkat Pendidikan}

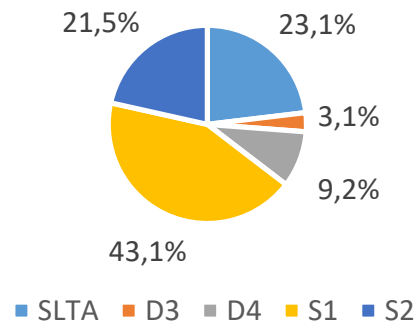

Dan dari tingkat pendidikan responden dapat diketahui bahwa: pendidikan SLTA atau sederajat berjumlah 15 responden atau sebesar 23,1\%; tingkatan Diploma 3 sebanyak 2 responden (3,1\%); Diploma 4 sebanyak 6 orang $(9,2 \%)$; Strata 1 sebanyak 28 orang responden $(43,1 \%)$; dan pendidikan Strata 2 sebanyak 14 orang responden $(21,5 \%)$. Berdasarkan uraian tersebut, responden terbanyak di Pusat Pengembangan Sumber Daya Manusia Kementerian Dalam Negeri Regional Bukittinggi adalah yang berasal dari tingkat pendidikan Strata 1, yaitu sebanyak 28 orang $(43,1 \%)$ dan paling sedikit pada tingkat pendidikan Diploma 3 yaitu sebanyak 2 orang atau 3,1\%.

Persepsi Responden Terhadap Indikator Kinerja, Budaya Kerja dan Motivasi Berprestasi

a. Persepsi Terhadap Kinerja

Berdasarkan pengolahan data, dapat dilihat bahwasanya rata-rata Kinerja Pegawai di PPSDM Kementerian Dalam Negeri Regional Bukittinggi berada pada kategori tinggi yang memiliki nilai mean 2.88 dan TCR sebesar 72.02. Nilai rata-rata mean dan TCR variabel kinerja yang berada pada kategori tinggi ini menunjukkan bahwa kinerja pegawai PPSDM Kementerian Dalam Negeri Regional Bukittinggi tinggi. Kinerja yang tinggi ini disebabkan karena pegawai PPSDM yang bekerja di sana memiliki kualitas kerja yang lebih baik.

\section{b. Persepsi Terhadap Budaya Kerja}

Berdasarkan pengolahan data, dapat dilihat bahwasanya rata-rata variabel Budaya Kerja pegawai di PPSDM Kementerian Dalam Negeri Regional Bukittinggi berada pada kategori sangat tinggi yang memiliki nilai mean 3,39 dan TCR sebesar 84,80. Dari nilai-nilai mean dan TCR berdasarkan tiaptiap indikator budaya kerja di atas, penulis mengambil kesimpulan bahwa pegawai di PPSDM Kementerian Dalam Negeri Regional Bukittinggi sudah memiliki pemahaman yang baik terhadap budaya kerja beserta indikator - indikator penyusunnya. Ketika budaya kerja dipahami dalam pelaksanaan tugas, maka bisa dipastikan bahwa pegawai dalam organisasi tersebut akan menjalankan tugas pokok dan fungsinya yang sejalan dengan visi dan misi organisasi tersebut. Budaya kerja yang baik akan menentukan bagaimana kinerja suatu organisasi dapat terus bertahan dan meningkatkan kinerjanya. 


\section{c. Persepsi Terhadap Motivasi Berprestasi}

Berdasarkan pengolahan data, bahwasanya rata-rata variabel Motivasi Berprestasi di PPSDM Kementerian Dalam Negeri Regional Bukittinggi berada pada kategori tinggi yang memiliki nilai mean 2,84 dan TCR sebesar 70.94. Jika dilihat lebih detail kepada indikator-indikator penyusun variabel motivasi berprestasi, ada dua indikator berada pada nilai sangat tinggi dan dua indikator yang berada pada nilai cukup tinggi.

Dua indikator yang berada pada kategori sangat tinggi berada pada indikator nomor 10 (saudara lebih menyukai menyelesaikan pekerjaan secara team work dengan sesama rekan kerja) dengan nilai mean 3,29 serta nilai TCR 82,31 dan pada indikator nomor 17 (saudara dalam pengambilan keputusan akan memusyawarahkan dengan atasan dan rekan kerja sekantor) dengan nilai mean 3,28 dan TCR 81,92.

Hal ini dapat diartikan bahwa pegawai di PPSDM Kementerian Dalam Negeri Regional Bukittinggi lebih menyukai bekerja bersama team work sehingga kegiatan pendidikan dan pelatihan (Diklat) yang dilakukan sebagai program kerja akan berjalan sesuai rencana karena ada keterlibatan semua pihak. Pengambilan keputusan secara musyawarah juga merupakan langkah yang sangat baik dalam memecahkan masalah yang nantinya akan timbul dan juga sebagai apresiasi bagi pegawai untuk memberi sumbangsih pikirannya dalam memajukan organisasi.

Sementara indikator pada kategori cukup tinggi berada pada indikator nomor 11 (lingkungan kerja saat ini kurang memberikan peluang untuk aktulisasi diri bagi pegawai) dengan nilai mean 2,42 serta TCR 60,38 dan pada indikator nomor 18 (saudara kurang puas jika masukan dan arahan yang saudara berikan tidak didengarkan dan dilaksanakan dengan baik). Dari indikator nomor 11 dan 18 terlihat bahwa aktualisasi diri bagi pegawai belum diberikan ruang yang cukup luas untuk mengembangkan dirinya serta potensinya.

Hal ini dapat menyebabkan kejenuhan dalam bekerja dan pegawai akan merasa tidak dihargai karena kurangnya peluang tersebut. Dalam mengembangkan suatu organisasi diperlukan juga masukan dari para pegawai untuk melihat potensi apa yang bisa dikembangkan serta apa saja yang harus dievaluasi dari sisi yang berbeda, karena pegawai pada level bawah yang lebih sering bersinggungan dan terlibat langsung dengan para peserta Diklat.

\section{Pengaruh Budaya Kerja (XI) Terhadap Motivasi Berprestasi (X2)}

Berdasarkan hasil penelitian yang peneliti lakukan, terdapat hasil bahwa Budaya Kerja berpengaruh signifikan terhadap Motivasi Berprestasi. Pengaruh tersebut sebesar 0,424 (42,4\%). Berdasarkan hal tersebut dapat dijelasakan bahwa Budaya Kerja dapat mempengaruhi Motivasi Berprestasi di PPSDM Kementerian Dalam Negeri Regional Bukittinggi serta mampu mempengaruhi Motivasi Berprestasi secara signifikan.

Jadi berdasarkan hasil penelitian dan kajian teori serta deskripsi variabel yang peneliti dapatkan maka dapat peneliti simpulkan bahwa Budaya Kerja dapat mempengaruhi Motivasi Berprestasi pegawai di PPSDM Kementerian Dalam Negeri Regional Bukittinggi. Hal ini dapat dideskripsikan apabila Budaya Kerja seperti yang telah diuraikan berdasarkan indikator sebelumnya, maka secara teori dan hasil uji hipotesa, meningkatnya Motivasi Berprestasi disebabkan oleh Budaya
Kerja yang baik di Pusat Pengembangan Sumber Daya Manusia Kementerian Dalam Negeri Regional Bukittinggi.

\section{Pengaruh Budaya Kerja (XI) Terhadap Kinerja (Y)}

Berdasarkan hasil penelitian yang peneliti lakukan, didapat hasil bahwa variabel Budaya Kerja berpengaruh terhadap variabel Kinerja pegawai. Dengan demikian dapat dijelaskan bahwa variabel Budaya Kerja dapat mempengaruhi variabel Kinerja di Pusat Pengembangan Sumber Daya Manusia Kementerian Dalam Negeri Regional Bukittinggi dan mampu mempengaruhi variabel Kinerja secara signifikan. Nilai pengaruh variabel Budaya Kerja terhadap Kinerja adalah sebesar 0,443 atau 44,3\%. Dengan kata lain semakin baik variabel Budaya Kerja diterapkan, maka variabel Kinerja akan semakin baik dan begitu juga sebaliknya.

Jadi berdasarkan hasil penelitian dan kajian teori serta deskripsi variabel yang peneliti dapatkan, maka dapat peneliti simpulkan bahwa variabel Budaya Kerja dapat mempengaruhi variabel Kinerja di Pusat Pengembangan Sumber Daya Manusia Kementerian Dalam Negeri Regional Bukittinggi. Hal ini dapat dideskripsikan apabila tiap-tiap indikator dari variabel Budaya Kerja sesuai dengan harapan maka secara teori dan hasil penelitian akan meningkatkan Kinerja pegawai yang ada di Pusat Pengembangan Sumber Daya Manusia Kementerian Dalam Negeri Regional Bukittinggi.

\section{Pengaruh Motivasi Berprestasi (X2) Terhadap Kinerja (Y)}

Hasil penelitian ini menunjukkan bahwa variabel Motivasi Berprestasi berpengaruh terhadap variabel Kinerja pegawai. Sehingga dapat dijelaskan bahwa variabel Motivasi Berprestasi dapat mempengaruhi variabel Kinerja di PPSDM Kementerian Dalam Negeri Regional Bukittinggi dan mampu mempengaruhi variabel Kinerja secara signifikan. Nilai pengaruh variabel Motivasi Berprestasi terhadap Kinerja adalah sebesar 0,592 atau 59,2\%. Dengan kata lain semakin baik variabel Motivasi Brprestasi dijalankan, maka variabel Kinerja akan semakin baik dan begitu juga sebaliknya.

Jadi berdasarkan hasil penelitian dan kajian teori serta deskripsi variabel yang peneliti dapatkan, maka dapat peneliti simpulkan bahwa variabel Motivasi Berprestasi dapat mempengaruhi variabel Kinerja di Pusat Pengembangan Sumber Daya Manusia Kementerian Dalam Negeri Regional Bukittinggi. Hal ini dapat dideskripsikan apabila tiap-tiap indikator dari variabel Motivasi Berprestasi sesuai dengan harapan maka secara teori dan hasil penelitian akan meningkatkan Kinerja pegawai yang ada di PPSDM Kementerian Dalam Negeri Regional Bukittinggi.

\section{Pengaruh Budaya Kerja (XI) dan Motivasi Berprestasi (X2) Terhadap Kinerja $(Y)$}

Berdasarkan hasil penelitian yang peneliti lakukan, didapat hasil bahwa variabel Budaya Kerja dan Motivasi Berprestasi berpengaruh terhadap variabel Kinerja pegawai. Dengan demikian dapat dijelaskan bahwa variabel Budaya Kerja dan Motivasi Berprestasi dapat mempengaruhi variabel Kinerja di PPSDM Kementerian Dalam Negeri Regional Bukittinggi dan mampu mempengaruhi variabel Kinerja secara signifikan. Nilai pengaruh variabel Budaya Kerja dan Motivasi Berprestasi terhadap Kinerja adalah sebesar 0,634 atau 63,4\%. Dengan kata lain semakin baik variabel Budaya Kerja dan Motivasi 
Berprestasi diterapkan, maka variabel Kinerja akan semakin baik dan begitupun sebaliknya.

Jadi berdasarkan hasil diatas serta kajian teori yang peneliti dapatkan, maka dapat peneliti simpulkan bahwa Budaya Kerja dan Motivasi Berprestasi dapat mempengaruhi Kinerja pegawai di PPSDM Kementerian Dalam Negeri Regional Bukittinggi. Hal ini dapat dideskripsikan apabila variabel Budaya Kerja dan Motivasi Berprestasi seperti indikator yang telah diuraikan sebelumnya sudah sesuai harapan, maka secara teori dan hasil penelitian akan meningkatkan kinerja pegawai dalam memberikan Pendidikan dan Pelatihan (Diklat) di PPSDM Kementerian Dalam Negeri Regional Bukittinggi.

\section{Pengaruh Budaya Kerja Terhadap Kinerja Melalui Motivasi Berprestasi}

Penelitian ini menunjukkan bahwa terdapat pengaruh tidak langsung antara variabel Budaya Kerja terhadap variabel Kinerja melalui Motivasi Berprestasi. Dari hasil pengolahan data secara tidak langsung diketahui bahwa pengaruh variabel Budaya Kerja terhadap Kinerja melalui Motivasi Berpestasi berpengaruh signifikan. Berdasarkan hal tersebut maka dapat dikatakan bahwa selain memiliki pengaruh langsung Budaya Kerja terhadap kinerja juga di pengaruhi oleh pengaruh tidak langsung Budaya Kerja terhadap kinerja melalui Motivasi Berprestasi, dengan kata lain Budaya Kerja juga akan mampu meningkatkan kinerja melalui Motivasi Berprestasi. Pengaruh tidak langsung antara variabel Budaya Kerja terhadap Kinerja melalui Motivasi Berprestasi ini adalah sebesar 11,12 \%. Besaran ini dapat dikatakan cukup berpengaruh di lokasi penelitian. Karena tidak semua lokasi penelitian dapat menghasilkan nilai yang sama. Hasil ini dapat dikatakan bahwa budaya kerja tidak hanya berpengaruh secara langsung terhadap kinerja, tetapi juga dapat melalui motivasi berprestasi yang dimiliki oleh para pegawai.

\section{KESIMPULAN}

Berdasarkan hasil penelitian dan kajian teori yang peneliti dapatkan maka dapat peneliti simpulkan bahwa Budaya Kerja dapat mempengaruhi kinerja melalui motivasi berprestasi yang dimiliki oleh pegawai di PPSDM Kementerian Dalam Negeri Regional Bukittinggi, hal ini dapat dideskripsikan Kinerja akan meningkat bukan hanya dipengaruhi Budaya Kerja saja tapi juga akan mampu meningkatkan Kinerja melalui Motivasi Berprestasi.

\section{REFERENSI}

AA. Anwar Prabu Mangkunegar. (2000). Manajemen Sumber Daya Manusia Perusahaan. Bandung: PT. Remaja Rosdakarya.

Ahmad Jamaluddin. (2015). Metode Penelitian Administrasi Publik (Teori dan Aplikasi). Yogyakarta: Penerbit Gava Media

Akdon Riduwan. (2012). Rumus dan Data dalam Aplikasi Statistika. Cetakan I. Bandung: Alfabeta.

Aldri Frinaldi. (2017). Mengelola Budaya Organisasi dan Budaya Kerja. Padang: UNP PRESS

Dessler, Gary. (2009). Manajemen SDM. Jakarta: Indeks.

Faustino, Cardoso Gomes. (2003). Manajemen Sumber Daya Manusia. Yogyakarta: Andi Offset.

Gibson. (2008). Manajemen Sumber Daya Manusia. Edisi Keempat. Jakarta: Erlangga.
Malayu Hasibuan. (2001). Manajemen Sumber Daya Manusia. Jakarta: Bumi Aksara.

Mangkunegara, Anwar Prabu. (2005). Evaluasi Kinerja SDM. Bandung: Refika Aditama.

Mathis dan Jackson. (2002). Manajemen Sumber Daya Manusia. Edisi Pertama. Cetakan Pertama. Yogyakarta: Salemba Empat.

Mink. (1993). Manajemen Sumber Daya Manusia (Kinerja). Cet.4. Jakarta: PT. Elex Media Komputindo.

Moekijat. (2006). Asas-asas Prilaku Organisasi. Bandung: CV. Bandar Maju.

Muhammad Fadel \& Rayendra L. Toruan. (2009). Reinventing Local Government: Pengalaman Dari Daerahi. Jakarta: Elex Media Komputindo.

Nawawi Hadari. (2003). Manajemen Sumber Daya Manusia Untuk Bisnis yang Kompetitif. Yogyakarta: Gajah Mada University Press.

Ndraha, Taliziduhu. (2005). Teori Budaya Organisasi. Jakarta: PT. Rineka Cipta.

Osborn dan Plastrik. (2002). Manajemen Sumber Daya Manusia. Yogyakarta: BPFE.

Prasetya, Triguna. (2001). Manajemen Sumber Daya Manusia. Jakarta: Bumi Aksara.

(2003). Budaya Kerja (Falsafah, Tantangan, Lingkungan yang kondusif, Kualitas, Pemecahan Masalah). Jakarta: PT. Golden Terayon Press. 